\title{
Upaya Pencegahan dan Penanganan Kredit Macet Ditinjau dari Persepsi Nasabah
}

\author{
Eriska Ajeng Ade Putri ${ }^{1}$, Elva Nuraina ${ }^{2}$, Elana Era Yusdita ${ }^{3}$ \\ 1,2,3 Universitas PGRI Madiun, Jawa Timur, Indonesia
}

\section{INFO ARTIKEL \\ JEL Classification :}

E51, E59

Keywords :

non perfoming loan, customer perception, behavioral accounting

\begin{abstract}
This research aims to minimize or avoid nonperforming loan problems by knowing the perspective side of the customer which the bank does not know. The type of research used is a qualitative approach. Data collection techniques through interviews and observations. The findings of the study show that (1) In the procedure for granting credit, there are requirements if a customer who wishes to apply for a loan also includes collateral and a mutation in the customer's savings account balance. (2) Loans given by Banks, especially the type of KUR (People's Business Credit) are primarily intended for people who wish to establish or de-velop their businesses, however some of the funds are used for personal purposes and also deposit loan funds at the Bank. (3) According to customer perceptions, the factors causing nonperforming loan are mainly due to business failure, coupled with the Covid-19 pandemic. (4) Preventive measures that can be taken are conducting customer business surveys by focusing on opportunities for customer to earn income or paying attention to the customer's business chan. Handling measures that can be taken are by means of credit restructuring or credit extension by the bank.
\end{abstract}

\begin{abstract}
ABSTRAK
Penelitian ini bertujuan untuk meminimalisir atau menghindari masalah kredit macet dengan mengetahui sisi presepktif dari nasabah yang tidak diketahui oleh bank. Jenis penelitian yaitu pendekatan kualitatif. Teknik pengumpulan data melalui wawancara dan observasi. Hasil temuan penelitian menunjukan bahwa (1) Dalam prosedur pemberian kredit terdapat persyaratan jika nasabah yang hendak mengajukan pinjaman juga menyertakan agunan dan mutasi saldo rekening tabungan nasabah. (2) Pinjaman yang diberikan bank khususnya jenis KUR (Kredit Usaha Rakyat) utamanya diperuntukan bagi masyarakat yang hendak mendirikan atau mengembangkan usahanya, namun ada sebagian dana yang digunakan untuk kepeluan pribadi dan juga mendepositokan dana pinjaman di bank. (3) Menurut persepsi nasabah faktor penyebab kredit macet utamanya karena kegagalan bisnis ditambah lagi dengan adanya pandemi covid-19. (4) Upaya pencegahannya yaitu melakukan survei usaha nasabah dengan berfokus pada peluang nasabah dalam memperoleh pendapatan atau memperhatikan rantai bisnis nasabah. Upaya penanganannya yaitu dengan cara rekstrukturisasi kredit atau perpanjangan masa kredit yang dilakukan oleh pihak bank.
\end{abstract}




\section{Pendahuluan}

Kredit berperan penting untuk menunjang per-tumbuhan ekonomi masyarakat. Berdasarkan Undang-Undang Republik Indonesia Nomor 10 Tahun 1998 Tentang Perubahan Atas Undang-Undang Nomor 7 Tahun 1992 Tentang Perbankan (1998), menyatakan kredit adalah penyediaan dana yang dapat dipersamakan dengan itu, berdasarkan perjanjian serta kesepakatan bersama antara calon nasabah dan pihak lembaga keuangan. Pemberian pinjaman atau kredit sudah bukan sesuatu yang asing lagi di Indonesia bahkan hampir di seluruh pelosok nusantara selalu ada tempat atau lembaga yang khusus menyediakan pinjaman bagi setiap individu yang membutuhkan.

Bank XYZ adalah salah satu lembaga per-bankan nasional yang sampai saat ini telah menun-jukan konsistensinya dalam melayani nasabahnya, masyarakat tidak segan lagi untuk berkunjung ke bank dan menikmati layanan perbankan. Bank XYZ juga menyediakan fasilitas pemberian dana pin-jaman yang khusus atau diperuntukan bagi masyarakat yang hendak mendirikan atau mengembangkan usahanya atau yang lebih dikenal dengan pinjaman KUR (Kredit Usaha Rakyat). Mahadi (2019) menjelaskan pada tahun 2015 bunga KUR masih 12\%, pada tahun 2016 turun menjadi $9 \%$, pada tahun 2018 bunga KUR turun lagi pada angka $7 \%$ dan bertahan sampai dengan tahun ini. Namun setelah itu pemerintah resmi menurunkan suku bunga KUR dari 7\% menjadi $6 \%$ pada tahun 2020 dan tidak hanya itu plafon penyaluran KUR juga naik signifikan 36\% dari Rp 140 triliun menjadi Rp 190 triliun tahun 2020, hal ini dilakukan untuk upaya menjaga konsistensi Bank XYZ dimata masyarakat dan oleh sebab itu masyarakat tertarik untuk mengajukan pinjaman khususnya KUR di Bank XYZ. Menurut Departemen Komuniksasi (2019), menjelaskan bahwa pertumbuhan kredit diperkirakan meningkat pada triwulan IV 2019 dan terdapat data dari Otoritas Jasa Keuangan (2019), berupa laporan publikasi bulanan neraca PT Bank XYZ yang mengalami peningkatan pada nilai kredit dari triwulan IV pada tahun 2019.

Pada saat ini di negara Indonesia sedang mengalami pandemi virus COVID-19 yang membu-at sebagian sektor bisnis mengalami penurunan pendapatan. Tentunya hal ini menjadi masalah bagi masyarakat atau pengusaha yang memiliki kewajiban untuk membayar pinjaman, jika pin-jaman tersebut tidak dibayarkan maka akan timbul masalah yaitu kredit macet atau kredit bermasalah. Dalam perbankan juga terjadi permasalahan mengenai adanya kredit macet atau kredit bermasa-lah, Hutauruk (2019), menjelaskan adanya masalah kredit macet perbankan meningkat di awal tahun 2019. Hal ini terjadi karena OJK melaporkan tingkat kredit macet perbankan pada Februari 2019 tercatat pada angka 2,59\% mengalami kenaikan 33\% dari bulan sebelumnya yaitu tercatat pada angka $2,56 \%$. Dengan demikian tentunya menjadi indikasi adan-ya kredit macet di perbankan yang menjadi perma-salahan yang harus diatasi oleh lembaga keuangan khusunya perbankan.

Penelitian tentang kredit macet selama ini hanya berfokus pada sisi pengendalian bank, misalnya Putra, Widarsono, \& Nasim (2017), Pra-sadhana, Sulindawati, \& Sinarwati (2017), Anasthasia, Darmawan, \& Werastuti (2015), Papal-angi (2013), dan di koperasi oleh Nawangsari \& Putra (2016). Padahal dalam proses pengajuan kred-it, ada dua pihak yang terlibat, yaitu kreditur dan debitur. Sistem kredit yang dilakukan selama ini hanya disoroti dari pihak bank dan koperasi, se-hingga peneliti tertarik untuk menggali perspektif debitur mengenai proses pencairan, pemakaian, hingga pembayaran kredit. Harapannya adalah ada solusi untuk penanganan kredit macet, apalagi di masa wabah covid-19 yang adil untuk kedua pihak. Oleh karena itu, tujuan penelitian ini adalah meminimalisir atau menghindari masalah kredit macet dengan mengetahui sisi perspektif nasabah yang tidak diketahui oleh Bank mengenai persepsi debitur atau nasabah yang memiliki pinjaman KUR di Bank XYZ Madiun dalam upaya pencegahan dan penanganan kredit macet.

\section{Telaah Teori dan Pengembangan Hipotesis}

\section{A. Sistem Pengendalian Internal}

Menurut Mulyadi (2017), suatu sistem pada dasarnya adalah sekelompok unsur yang erat berhubungan dengan satu dan lainnya, yang berfungsi bersama-sama untuk mencapai tujuan tertentu. Kemudian definisi sistem pengendalian internal yaitu suatu sistem yang meliputi struktur organisasi, metode dan 
ukuran-ukuran yang dikoordinasikan untuk menjaga aset organisasi, mengecek ketelitian dan keandalan data akuntansi, mendorong efesiensi dan mendorong dipatuhinya kebijakan manajemen. Dalam sistem pengendalian internal menurut Mulyadi (2017) terdapat empat unsur pokok sistem pengendalian internal adalah sebagai berikut:

1.Struktur organisasi yang memisahkan tanggung jawab fungsional secara tugas.

2. Sistem wewenang dan prosedur pencatatan yang memberikan perlindungan yang cukup terhadap aset, utang, pendapatan dan beban.

3.Praktik yang sehat dalam melaksanakan tugas dan fungsi setiap unit Organisasi.

4.Karyawan yang mutunya sesuai dengan tanggung jawabnya.

\section{B. Sistem Pemberian Kredit}

Dalam suatu sistem selalu ada unsur pengendalian internal didalamnya termasuk dalam sistem pemberian kredit. Pada penelitian yang dilakukan Yuliana \& Widianti (2014) mengenai sistem pemberian kredit pada unit simpan pinjam KUD Karya Mina Kota Tegal pengertian sistem pem-berian kredit adalah suatu prosedur atau rangkaian yang harus dilakukan dalam pen-yaluran kredit kepada kreditur dengan mem-perhatikan aturan atau ketentuan yang telah ditetapkan. Adapun menurut Fahmi (2014), beberapa hal yang harus diperhatikan dalam penilaian dan pengawasan kredit adalah se-bagai berikut:

1.Persyaratan Umum untuk Mengajukan Kredit, ada beberapa persyaratan umum dalam mengajukan kredit dalam lembaga perbankan dan harus dipenuhi dan dipatuhi oleh calon debitur atau nasabah diantaranya yaitu syarat administrasi meliputi: (1) Foto copi KTP, (2) Foto copi KK (Kartu keluarga), (3) SK $80 \%$ dan $100 \%$ (80\% khusus bagi PNS, namun jika pegawai swasta juga memiliki supaya turut diikutsertakan), (4) NPWP (Nomor Pokok Wajib Pajak), (5) Sertifikat kepemilikan rumah atau tanah sebagai jaminan maupun BPKB kendaraan bermotor, (6) Buku tabungan, (7) Surat keterangan tempat bekerja, (8) Slip gaji 3 atau 4 bulan terakhir, (9) Mengisi formulir pengajuan kredit, (10) Surat keterangan sanggup membayar cicilan kredit pada saat masa pensiun kerja semakin dekat.
2.Penilaian Kredit, dalam pengajuan kredit terdapat beberapa penilaian yang harus dilakukan salah satunya adalah analisis penilaian yang dikenal dengan analisis 6C. Afriana (2017) melakukan penelitian mengenai analisis implementasi $6 \mathrm{C}$ terhadap kelancaran pengembalian kredit, yang dimaksud dengan $6 \mathrm{C}$ adalah sebagai berikut:

a) Character (Karakteristik)

b) Capacity (Kemampuan)

c) Capital (Modal)

d) Collateral (Jaminan)

e) Condition (Kondisi Perekonomian)

f) Constrain (Batasan atau Hambatan)

\section{Kredit dan Kredit Macet}

1. Kredit

Berdasarkan Undang-Undang Republik Indonesia Nomor 10 Tahun 1998 Tentang Perubahan Atas Undang-Undang Nomor 7 Tahun 1992 Tentang Perbankan (1998), definisi kredit adalah penyediaan uang atau tagihan berdasarkan persetujuan atau kesepakatan pinjam meminjam antara bank dengan pihak lain yang mewajibkan pihak peminjam melunasi utangnya setelah jangka waktu tertentu dengan pemberian bunga. Dalam kredit ada beberapa unsur yang harus diperhatikan, menurut Fahmi (2014:6), unsur-unsur kredit adalah sebagai berikut:

a) Kepercayaan

b) Waktu

c) Risiko

d) Prestasi

e) Adanya Kreditur

f) Adanya Debitur

Dalam penyaluran kredit fungsi kredit adalah dapat memberi pengaruh pada masyarakat utamanya pada perekonomian dan untuk mempercepat proses pembangunan. Adapun fungsi kredit perbankan dalam aktivitas perekonomian suatu negara menurut Fahmi (2014), adalah:

a) Fungsi kredit untuk berusaha memposisikan uang sebagai alat pertukaran yang efektif

b) Fungsi kredit sebagai penyaluran dana dan pembinaan bagi dunia usaha

c) Fungsi kredit sebagai pengawasan moneter

d) Fungsi kredit sebagai bagian untuk menghindari pemutusan finansial

e) Fungsi kredit untuk menciptakan suatu pemerataan pendapatan 
f) Fungsi kredit sebagai salah satu alat dalam menggairahkan bisnis InternasionalFungsi kredit untuk meningkatkan aktivitas penggunaan barang dan jasa

g) Fungsi kredit sebagai pendorongan dan pencipta stabilitas ekonomi.

Dalam penyaluran kredit kepada kreditur analisis untuk mengkaji secara seri-us terhadap pengajuan atau suatu permohonan kredit dari sesorang indi-vidu atau lembaga yang membutuhkan dana guna membiayai suatu pengerjaan proyek atau usaha penting dilakukan. Hal ini bertujuan untuk menjelaskan secara rinci tentang ke-mampuannya untuk mampu mengem-balikan pinjaman tersebut secara tepat waktu dan siap menanggung segala risiko yang akan terjadi. Menurut Fahmi (2014), untuk membuat analisis ke-layakan tersebut menjadi lebih kuat maka perlu diperhatikan beberapa aspek yang tidak bisa dihilangkan dalam kajian kelayakan yaitu sebagai berikut:

a) Aspek Manajemen (Management Aspect)

b) Aspek Keuangan (Financial Aspect)

c)Aspek Pemasaran (Marketing Aspect)

d) Aspek Produksi (Production Aspect)

e) Aspek Teknis (Tehnical Aspect)

f) Aspek Kemanfaatan (Benefit Aspect)

g) Aspek Yuridis (Juridical Aspect)

h) Aspek Kesempatan Kerja (Opportunity Job Aspect)

\section{Kredit Macet}

Ismail (2010:218), menjelaskan kredit bermasalah adalah suatu keadaan di mana nasabah sudah tidak sanggup membayar sebagian atau seluruh kewajibannya kepada bank seperti yang telah diperjanjikan. Kemudian menurut Hasibuan (2011:115), kredit macet adalah kredit yang diklasifikasikan pembayarannya tidak lancar yang dilakukan oleh debitor yang bersangkutan. Nama lain dari kredit bermasalah adalah kredit macet, kredit bermasalah memiliki dampak buruk bagi bank yaitu kerugian karena tidak diterimanya kembali dana yang telah disalurkan maupun bunga yang tidak dapat diterima yang berarti bank akan mengalami penurunan pendapatan bunga dan juga pendapatan secara keselurahan. Jadi kredit macet adalah bagian dari piutang yang tidak dapat ditagih, dimana keadaan nasabah sudah tidak mampu membayar kewajibannya kepada pihak lembaga keuangan dan akan mengakibatkan kerugian pada pihak lembaga keuangan.

Beberapa faktor penyebab kredit macet menurut Ismail (2010), berasal dari internal bank dan eksternal bank berikut adalah penjelasannya.

1. Faktor Intern Bank

a.Kurang cermat dalam melakukan analisis terhadap nasabah sehingga tidak dapat mengetahui hambatan yang terjadi selama jangka waktu kredit.

b.Pejabat bank yang memiliki itikad tidak baik dalam memberikan kredit kepada nasabah

c. Dalam melakukan analisis kelayakan usaha nasabah pihak bank memiliki keterbatasan pengetahuan sehingga analisis kredit yang dilakukan belum tepat.

d. Terdapat campur tangan komisaris dan direktur bank yang menyebabkan petugas bank kesulitan dalam memutuskan kredit.

e. Kurang rutin dalam melakukan monitoring kredit

2. Faktor Ekstern Bank

a.Pihak debitur yang sengaja tidak membayar angsuran atau tidak memenuhi kewajibannya

b.Pihak debitur yang sedang melakukan perkembangan usaha sehingga membutuhkan dana yang besar, hal ini berpengaruh dalam memenuhi kebutuhan modal kerja.

c. Adanya penyelewengan yang dilakukan nasabah misalnya dalam pengajuan kredit, nasabah mengajukan kredit investasi namun pada kenyataanya setelah kredit diberikan kredit tersebut digunakan untuk modal kerja.

d.Adanya sesuatu yang tidak terduga misalnya bencana alam, ketidakstabilan ekonomi atau sedang terjadi inflansi

Hasibuan (2011:115), menjelaskan ada beberapa cara yang dapat dilakukan un-tuk menangai kredit macet adalah se-bagai berikut:

1. Resheduling (penjadwalan kembali)

2. Reconditioning (persyaratan kembali)

3 . Restructuring (penataan kembali)

4. Liquidation 


\section{Risiko Bisnis}

Pengertian risiko mempunyai ragam arti lain seperti bahaya, keraguan atau adanya dua kemugkinan mengalami kerugian atau keuntungan (Manullang, 2013). Risiko bisnis adalah risiko pemberian kredit yang timbul semata-mata disebabkan oleh faktor murni yang bersifat bisnis, seperti kerugian pasar, kondisi pasar yang tidak stabil dan kebagkrutan. Resiko usaha adalah suatu bahaya, atau akibat yang kemungkinan dapat terjadi pada keadaan sebuah usaha yang sedang berlangsung maupun situasi usaha yang akan datang. Sifat dari resiko usaha itu sendiri adalah tidak pasti dan sebagian besar menimbulkan kerugian. Risiko usaha merupakan situasi yang tidak dikehendaki oleh para pelaku bisnis, namun resiko usaha sendiri selalu tidak bisa dihindarkan. Resiko usaha biasanya muncul karena faktor pelaku bisnis itu sendiri dan dapat muncul karena kegiatan dan keputusan yang diambil dalam kegiatan rutinitas sehari-hari. Resiko dapat bersifat pasti maupun tidak pasti, tergantung dari usaha yang dijalankan dan bagaimana cara menjalankan usaha tersebut.

Menurut Manullang (2013:256), ada berbagai jenis risiko, namun secra garis besar dibedakan atas dua jenis utama yaitu:

\section{Pure Risk (Risiko Murni)}

Yaitu resiko yang bilamana terjadi, pasti akan memberikan kerugian, contoh dari resiko murni adalah seperti pencurian, bencana alam, kebakaran atau kecelakaan..

2. Speculative Risk (Risiko Spekulasi)

Yaitu resiko yang bilama terjadi belum pasti mengakibatkan kerugian,

Selama suatu usaha masih berjalan atau masih menjalankan kegiatan operasional-nya maka hal tersebut tidak terlepas dari risiko. Secara teknis, proses menangai risiko dimulai dari indentifikasi kejadian risiko yang bersangkutan, mengadakan penilaian tertentu terhadap risiko dan akhirnya pem-ilihan serta metode atau cara yang digunakan untuk penaganan risiko dan cara mengatasi risiko (Manullang 2013:257). Berikut adalah gambar cara menangani risiko, pada umunya ada tujuh cara bagi pe-rusahaan dalam menanagani risiko yaitu sebagai berikut:

1. Risk Advoidance (Penghidaran Risiko)

2. Risk Reduction (Penurunan Risiko)

3. Risk Retention (Menahan Risiko)
4. Risk Sharing (Membagi Risiko)

5. Risk Transfer (Mengalihkan Risiko)

6. Risk Hedging (Membendung Risiko)

7. Self Insurance (Menyelenggarakan Asuransi

\section{Metode Penelitian}

Pada penelitian ini jenis penelitian yang digunakan yaitu pendekatan kualitatif, karena penelitian berdasarkan dengan penemuan suatu fenomena sosial atau masalah manusia yang sedang terjadi saat ini. Penelitian dilakukan di rumah dan lokasi usaha debitur atau nasabah Bank XYZ Madiun yang bertempat diwilayah Kota Madiun dan Kabupaten Madiun Provinsi Jawa Timur. Sum-ber data yang digunakan dibagi menjadi 2 yaitu data primer dan data sekunder. Data primer berupa data dari hasil melakukan wawancara dengan lima informan yang memiliki pinjaman KUR di Bank XYZ Madiun dan data hasil observasi dengan mengamati beberapa aspek yang diperlukan.

Data sekunder yang diperlukan adalah jurnal dan artikel yang terkait dengan masalah penelitian yaitu mengenai persepsi debitur atau nasabah. Kemudian instrumen yang akan digunakan yaitu lembar wawancara dan lembar obervasi dengan teknik pengumpulan data melalui wawancara, ob-servasi, dan dokumentasi. Adapun teknik analisis data dalam penelitian ini yaitu menggunakan analisis data dengan model interaktif atau interactive model yang memiliki beberapa komponen yaitu (1) Data Reduction, (2) Data Display, (3) Conclusion Draw-ing/Verification. Kemudian untuk membuktikan data yang diperoleh peneliti valid, maka digunakan analisis triagualasi data dengan menggunakan triagulasi teknik dan sumber.

\section{Hasil Penelitian dan Pembahasan}

Dalam bagian pembahasan hasil penelitian, peneliti akan menguraikan masing-masing mengenai hasil analisis data dengan berfokus pada masalah penelitian yaitu menjawab mengenai bagaimana persepsi nasabah yang memiliki pinjaman KUR di Bank XYZ Madiun dalam upaya pencegahan dan penanganan untuk meminimalisir adanya kredit macet. Peneliti akan mendeskripsikan hasil analisis data dengan melakukan kesesuaian dengan teori atau pustaka dengan hasil data yang diperoleh peneliti setelah melakukan wawancara dengan 
lima informan yang merupakan nasabah Bank XYZ Madiun dan juga memiliki pinjaman KUR (Kredit usaha rakyat) dan observasi mengenai usaha yang dimiliki kelima infoman tersebut. Berikut profil singkat para informan tersebut:

Informan satu (Mawar) memiliki pinjaman KUR (Kredit Usaha Rakyat) di Bank XYZ Madiun yang dimana dana pinjamannya diperuntukan untuk bisnis usaha makanan dan minuman (Food and Beverage) yaitu kedai kopi yang berlokasi disekitar Kota Madiun, usaha tersebut sudah tiga tahun berdiri dan sampai dengan sekarang usaha tersebut masih eksis dilihat dari minat masyarakat madiun yang semakin hari meningkat untuk berkunjung dikedai kopi tersebut.

Informan dua (Melati) memiliki pinjaman KUR (Kredit Usaha Rakyat) di Bank XYZ Madiun yang dimana dana pinjamannya diperuntukan untuk yaitu untuk bisnis usaha makanan dan minuman (Food and Beverage) kedai ayam geprek yang berlokasi disekitar Kota Madiun, usaha tersebut sudah hampir dua tahun berdiri dan sampai dengan sekarang usaha tersebut masih berdiri dan berjalan baik dengan dilihat dari banyaknya customer.

Informan tiga (Matahari) memiliki pinjaman KUR (Kredit Usaha Rakyat) di Bank XYZ Madiun yang dimana dana pinjamannya diperuntukan untuk untuk bisnis usaha makanan dan minuman (Food and Beverage) yaitu warung makan sederhana yang berlokasi disekitar Kabupaten Madiun, usaha tersebut sudah hampir dua puluh tahun berdiri dan sampai dengan sekarang usaha tersebut masih berdiri dan berjalan baik dengan dilihat dari banyaknya customer.

Informan empat (Kamboja) memiliki pinjaman KUR (Kredit Usaha Rakyat) di Bank XYZ Madiun dan memiliki bisnis usaha makanan dan minuman (Food and Beverage) yaitu warung makan sederhana yang berlokasi disekitar Kota Madiun, usaha tersebut sudah hampir lima tahun berdiri dan sampai dengan sekarang usaha tersebut masih berdiri dan berjalan baik. Namun dana pinjamannya tidak diperuntukan untuk usahanya melainkan untuk keperluan lainnya diluar usaha.

Informan lima (Tulip) memiliki pinjaman KUR (Kredit Usaha Rakyat) di Bank XYZ Madiun yang dimana dana pinjamannya diperuntukan untuk bisnis pertanian yang berlokasi disekitar Kabupaten Madiun, usaha tersebut sudah sepuluh tahun berdiri dan sampai dengan sekarang usaha tersebut masih berdiri dan berjalan baik dengan dilihat dari kegiatan usaha yang terus berjalan dengan baik.

Untuk mendirikan suatu bisnis atau usaha tentunya peran modal atau dana sangatlah penting, oleh sebab itu terdapat beberapa lembaga keuangan yang menyediakan fasilitas pinjaman terlebih pinjaman tersebut dikhususkan bagi masyarakat yang hendak mendirikan usaha. Bank XYZ merupakan salah satu lembaga keuangan yang menyediakan fasilitas pinjaman KUR (Kredit usaha rakyat). Bunga yang diterapkan oleh Bank XYZ cukup ringan menurut Mahadi (2019) pada saat ini pemerintah telah resmi menurunkan suku bunga KUR di Bank XYZ dari 7\% menjadi 6\% selain itu plafon penyaluran KUR juga naik dari $36 \%$ dari 140 triliun menjadi 190 triliun. Namun seiring dengan penurunan bunga KUR tersebut terdapat adanya masalah yaitu kredit macet Hutauruk (2019) menjelaskan kredit macet meningkat diawal tahun 2019, hal tersebut terjadi karena OJK melaporkan tingkat kredit macet perbankan pada Febuari tercatat sebesar $2,59 \%$ mengalami kenaikan $0,3 \%$ dari bulan sebelumnya yaitu sebesar 2,56.

Dalam pengajuan kredit, diambil dari website Bank XYZ, adapun persyaratan yang diterapkan oleh Bank XYZ adalah pertama individu atau perorangan yang melakukan usaha produktif dan layak, kedua telah melakukan usaha secara aktif minimal 6 bulan, ketiga tidak sedang menerima kredit dari perbankan kecuali kredit konsumtif seperti KPR, KKB dan kartu kredit dan keempat yaitu persyaratan administratif seperti KTP KK dan surat izin usaha. Kemudian pada saat ini Indonesia sedang mengalami pandemi virus covid-19 yang menyebabkan beberapa sektor bisnis mengalami penurunan pendapatan, Febrinastri (2020) menjelaskan terkait hal tersebut Bank $\mathrm{XYZ}$ membantu pedagang di pasar untuk melakukan rekstrukturisasi kredit agar dapat meringankan beban nasabah disaat masa pandemi virus covid-19.

Selanjutnya menurut persepsi nasabah mengenai cara untuk meminimalisir adanya kredit macet dapat dilakukan dengan cara upaya pencegahan sebelum terjadi kredit macet yaitu melakukan survei usaha nasabah, menghitung ke-mampuan bayar nasabah. Upaya penanganan setelah terjadi kredit macet yaitu rekstrukturisasi kredit dan menjual agunan atau jaminan nasabah yang mengalami kredit macet. 
Adapun berikut ada-lah uraian secara rinci dari masing-masing mengenai hasil analisis data dengan berfokus pada masalah penelitian:

\section{Analisis Prosedur Pengajuan Kredit}

Dalam tahapan awal pemberian kredit setiap lembaga simpan pinjam khususnya perbankan menerapkan beberapa prosedur dalam pemberian kredit. Adapun persyaratan yang diterapkan oleh Bank XYZ yang dikutip dari website Bank XYZ, yaitu pertama individu atau perorangan yang melakukan usaha produktif dan layak, kedua telah melakukan usaha secara aktif minimal 6 bulan, ketiga tidak sedang menerima kredit dari perbankan kecuali kredit konsumtif seperti KPR, KKB, dan kartu kredit dan yang keempat yaitu persyaratan administrasi seperti identitas berupa KTP, KK dan surat izin usaha. Kemudian kelima informan telah memenuhi persyaratan yang telah diterapkan oleh Bank XYZ, hanya saja di website Bank XYZ tersebut tidak disebutkan jika ada agunan dan mutasi buku rekening nasabah yang juga harus disertakan.

Selanjutnya masih terdapat hambatan dalam prosedur pemberian kredit terkait prosesnya yang membutuhkan waktu yang tidak bisa langsung, dari tahapan pengajuan sampai dengan keputusan kredit prosesnya paling cepat satu atau dua minggu dan paling lama sampai satu bulan. Selama dalam masa pandemi virus covid-19 Bank XYZ masih tetap dapat memberikan pinjaman hanya saja prosesnya membutuhkan waktu yang cukup lama karena perlu melakukan survei yang lebih ketat agar dapat mendapatkan hasil yang akurat. Selain itu untuk mengurus surat izin usaha juga memerlukan waktu dua hari sampai seminggu, hal tersebut dikarenakan proses dalam pembuatan SIUP dimulai dari permohonan izin kepada ketua RT setempat kemudian ketua RW setempat dan selanjutnya Kelurahan setempat. Jadi untuk membuat surat izin usaha membutuhkan proses dan memakan waktu atau tidak bisa langsung ,namun hal tersebut tidak menjadi masalah atau hambatan yang cukup besar jadi masih dalam kondisi yang wajar.

Hal ini mirip dengan hasil riset Pato (2013) yang melakukan penelitian mengenai analisis pemberian kredit mikro pada Bank Syariah Mandiri Cabang Manado. Hasilnya pihak Bank telah melaksanakan sesuai dengan prosedur yang ditetapkan dan melakukan analisis kredit mengenai penyelidikan berkas, permohonan BI Checking, permohonan penilaian agunan dan laporan on the spot atau kunjungan ke lokasi usaha maupun ke lokasi agunan untuk mengantasipasi terjadinya kredit macet. Kelima informan yang merupakan nasabah Bank XYZ dan juga memiliki pinjaman KUR tersebut, setelah mempersiapkan persyaratan adminstrasi dan menyerahkan ke kantor Bank XYZ selanjutnya informan menjelaskan jika kemudian terdapat pihak Bank yang melakukan survei ke tempat usaha nasabah. Selain itu pihak Bank XYZ juga melakukan pengecekan BI Checking, Pato (2013) menjelaskan suatu sistem yang disebut dengan Sistem Informasi Debitur (SID) adalah sistem yang dikelola Bank Indonesia dan di dalam sistem tersebut terdapat data para debitur setiap Bank yang merupakan anggota SID, dalam sistem tersebut juga terdapat istilah BI Checking yang dapat memperlihatkan riwayat debitur mengenai pinjaman yang menunggak atau tidak lancar. Dengan pengecekan riwayat BI Checking yang dilakukan oleh pihak Bank akan dapat mengetahui apakah nasabah mempunyai pinjaman di Bank lain dan tidak melunasi sesuai dengan waktu yang ditetapkan, dengan demikian akan dapat terlihat adakah kredit macet dari nasabah yang hendak melakukan pengajuan kredit tersebut hal tersebut akan menjadi pertimbangan pihak Bank dalam pemberian kreditnya kepada nasabah.

Kemudian dalam analisis penggunaan dana nasabah, sejatinya Bank XYZ memperuntukan dana pinjaman KUR (Kredit Usaha Rakyat) hanya untuk masyarakat yang hendak mendirikan usaha atau melakukan pengembangan usaha. Oleh sebab itu bunga pinjaman KUR sangat kecil jika dibandingkan dengan jenis pinjaman lainnya. Rahmawati, Saifi, \& Hidayat (2016) melakukan penelitian mengenai analisis keputusan pemberian kredit dalam langkah meminimalisir kredit bermasalah, hasilnya dengan memperhatikan condition of economy dan risiko bisnis yang akan dialami debitur dan analisis mantri akan berpengaruh terhadap pemberian kredit yang akan diberikan. Jadi dari penelitian tersebut dapat dipahami jika usaha atau bisnis yang dijalankan nasabah juga memiliki pengaruh dalam pemberian kredit.

Kelima informan telah merealisasikan dana pinjaman yang diterima untuk usahanya, seperti untuk membeli aset usaha yaitu meja, kursi, perlengkapan dan keperluan dapur dan 
juga untuk membeli bahan-bahan kebutuhan usaha. Namun, temuan uniknya adalah ada sebagian dana yang digunakan untuk keperluan pribadi informan dan ada juga yang mendepositokan dana pinjaman di bank lain, tetapi meskipun demikian tujuan informan dalam mengajukan pinjaman adalah utamanya untuk keperluan usaha dan selebihnya untuk keperluan diluar usaha. Kredit yang digunakan untuk deposito diungkapkan oleh Mawar,

"Dana yang saya terima sebagian saya langsung pergunakan untuk usaha saya pada saat itu untuk renovasi kedai saya. Selain itu sebagian danaya saya simpan atau saya depositokan di bank lain."

Sedangkan sebagian uang kredit yang digunakan untuk keperluan pribadi diungkapkan oleh Matahari dan Kamboja,

"Setelah permohonan kredit saya diterima kemudian dana tersebut sebagian saya realisasikan untuk pengembangan usaha saya, untuk membeli bahan-bahan pokok seperti sembako dan bahan yang lain. Namun sebagian dananya saya gunakan juga untuk keperluan saya pribadi, dan pada waktu permohonan pinjaman saya yang pertama dana pinjamannya juga saya realisasikan sama seperti “. (Matahari)

"Ya yang saya lakukan menggunakan dana tersebut untuk belanja keperluan usaha saya, untuk membeli sembako untuk belanja dagangan rokok juga. Namun tidak semuanya sebagian dana saya pergunakan untuk keperluan pribadi saya." (Kamboja)

\section{Analisis Upaya Pencegahan dan Penanganan Kredit Macet}

Dalam pemberian kredit tidak terlepas dari masalah kredit macet atau kredit bermasalah, tentunya terdapat dampak buruk dari adanya masalah kredit macet. Berdasarkan hasil wawancara dan observasi dengan Informan faktor penyebab kredit macet yang paling utama karena kegagalan bisnis nasabah. Ditambah lagi pada saat ini sedang terjadi pandemi virus covid-19 yang menyebakan penurunan ekonomi dan juga penurunan pendapatan bagi setiap pelaku usaha. Kelima informan mengaku mengalami penurunan omzet karena wabah dan faktor lainnya seperti gagal panen, tapi tidak sampai mengakibatkan kredit macet. Melati merestrukturisasi kredit untuk mencegah kredit macet. Hal ini menunjukkan ada itikad baik dari nasabah untuk berkomitmen menjaga kelancaran pembayaran kredit,

"Namun kemudian saya melakukan beberapa perencanaan dan simulasi untuk tetap berjalan dengan baik selama adanya pandemi virus COVID-19 ini. Salah satunya pengajuan rekstrukturisasi kredit di Bank XYZ supaya tidak memberatkan kami dalam melakukan pembayaran sehingga pada saat pandemi ini saya tidak megalami kredit macet."

Kelimanya menyadari bahwa karakter nasabah (dirinya sendiri) menjadi hal penting dalam pelunasan kredit tepat waktu. Bahkan Kamboja mengakui bahwa ia tidak pernah macet membayar, hanya lupa tanggal sehingga tidak tepat waktu,

"Saya tidak pernah mengalami kredit macet atau gak bayar, setiap bulan saya rutin membayar. Hanya saja mungkin telat tanggal yang seharusnya saya bayarkan tanggal 24 saya bayarkan tanggal 26 atau pernah mepet di akhir bulan.“

Namun selain itu terdapat faktor yang lain yaitu karakter dari nasabah itu sendiri, untuk mempelajari karakter seseorang bukan hal yang mudah akan tetapi pasti ada beberapa orang yang memiliki karakter kurang baik seperti tidak disiplin dalam waktu pembayaran, dana yang seharusnya digunakan untuk membayar angsuran namun dipergunakan untuk keperluan yang lain.

Kemudian menurut persepsi Informan mengenai info lelang rumah di Bank XYZ, terkait itu menurut Informan hal tersebut juga berkaitan dengan kredit macet. Informan tidak mengetahui secara detail mengenai info lelang Bank tersebut, namun sepengetahuan Informan apabila terdapat rumah, mobil atau agunan apapun yang dijual oleh Bank dengan cara dilelang, agunan tersebut merupakan agunan milik nasabah yang mengalami masalah dalam kreditmya. Selain itu jika ada agunan berupa rumah yang dijual oleh Bank itu bukan berasal dari pinjaman KUR melainkan seperti developer perumahan yang memang bisnisnya dibidang berjualan rumah kemudian rumah tersebut dijadikan jaminan jika hendak mengajukan pinjaman. Kemudian karena terdapat masalah seperti penipuan atau bangkrut sehingga developer perumahan tersebut tidak bisa membayar dan kemudian oleh Bank rumah tersebut disita dan dijual dengan cara dilelang.

Dalam upaya pencegahan kredit macet berdasarkan persepsi Informan adapun upaya 
yang dapat dilakukan yaitu pertama dengan melakukan survei secara tepat dan akurat. Survei yang dimaksud yaitu terkait usaha nasabah yang hendak melakukan pinjaman seperti mengetahui sebesar apa usahanya, pendapatan usaha dan menghitung kemampuan bayar berdasarkan pendapatan yang diterima, dan juga survei mengenai karakter nasabah juga perlu dilakukan. Kemudian yang kedua yaitu dengan menilai besaran agunan yang akan dijaminkan, jika tepat dalam menilai agunan maka jika ada yang megalami kredit macet maka akan bisa dijadikan penggantinya. Hohedu \& Dewi (2019) melakukan penelitian mengenai anlisis penanganan kredit macet pada Bank BRI cabang X, hasilnya adalah dalam penaganan kredit macet pihak Bank BRI melakukan prinsip kehati-hatian pegawai $\mathrm{AO}$ (Account Officer) dalam memilih nasabah dengan memperhatikan beberapa hal yang menjadi pertimbangan yaitu jenis usaha, karakter, dan kredibilitas nasabah yang hendak melakukan permohonan kredit. Jadi hal tersebut dapat dijadikan penentu atau sangat berpengaruh pada lancar atau tidaknya pembayaran angsuran nasabah dimasa mendatang.

Kemudian dalam upaya penangan kredit macet menurut persepsi nasabah hal yang dapat dilakukan bank yaitu pertama menagih dan mendatangi terkait nasabah yang memiliki pinjaman tersebut untuk dimintai keterangan mengenai apa penyebab sehingga tidak dapat membayar, kemudian melakukan diskusi sehingga pihak bank dapat memberikan solusi. Selanjutnya yang kedua solusi yang diberikan yaitu perpanjangan masa kredit atau rekstrukturisasi kredit seperti yang sedang diterapkan pada saat pandemi ini dapat juga diterapkan meskipun tidak sedang masa pandemi. Adapun yang ketiga bentuk penangannya yaitu dengan menyita dan menjual agunan dari nasabah tersebut, hal tersebut terjadi jika memang kondisi nasabah sudah tidak mampu lagi membayar dan sebelumnya telah melakukan kesepakatan antara pihak Bank dengan nasabah yang terkait. Azisri (2017) melakukan penelitian mengenai pencegahan dan penanggulangan masalah kredit macet bagi nasabah perbankan di Kampung Sidomulyo Kabupaten Merauke, hasilnya adalah permasalahan kredit macet yang telah terjadi dikarenakan rendahnya pemahaman masyarakat mengenai hukum perbankan yang seharusnya pihak bank melakukan sosialisasi terlebih dahulu kepada masyarakat.

Selanjutnya menurut Azisri (2017) dalam upaya pencegahan kredit macet dapat dilakukan dengan cara (1) Pengawasan dan Pembinaan oleh Bank, (2) Penyelamatan oleh Bank, dan (3) Melalui rekstrukturisasi atau penataan kembali kredit. Kemudian untuk upaya penanggulangannya dapat dilakukan dengan cara (1) Penagihan oleh pihak perbankan, (2) Perdamaian para pihak, (3) Penyelesaian kredit melalui jalur hukum, (4) Penyelesaian kredit bermasalah secara damai dan (5) Eksekusi jaminan. Kurangnya pengetahuan masyarakat tentang perjanjian kredit dan risiko kredit macet akan menyebabakan terjadinya wanprestasi mengenai pemahaman tentang pencegahan dan penanggulangan kredit macet yang akan dapat menambah angka kredit macet atau meningkatkan masalah kredit macet.

\section{Persepsi Nasabah Yang Memiliki Pinjaman KUR di Bank XYZ Dalam Meminimalisir Kredit Macet}

Dalam langkah untuk meminimalisir adanya kredit macet setiap lembaga keuangan termasuk perbankan telah menerapkan beberapa cara yang harus dilakukan. Terlebih lagi pada saat ini Indonesia sedang mengalami pandemi virus covid-19 yang memiliki dampak penurunan ekonomi dan penurunan pendapatan bagi setiap masyarakat memiliki usaha. Hal tersebut juga berdampak bagi pengusaha yang memiliki pinjaman di bank, apabila pendapatanya menurun kemudian tidak ada dana yang akan digunakan untuk membayar angsuran hal tersebut akan menimbulkan terjadinya kredit macet atau kredit bermasalah.

Febrinastri (2020) menjelaskan melalui berita suara.com jika Bank XYZ membantu pedagang di pasar untuk melakukan rekstrukturisasi kredit agar dapat meringankan beban nasabah disaat masa pandemi virus covid-19. Sebagai perbandingan dan informasi tambahan, Wiratmini (2020) menjelaskan cara untuk meminta keringan kredit di Bank XYZ adalah sebagai berikut pertama nasabah yang mengalami penurunan omset sampai $30 \%$ rekstrukturisasi berupa penurunan suku bunga dan perpanjangan waktu kredit, kedua nasabah yang mengalami penurunan omset $30 \%$ sampai $50 \%$ rekstrukturisasi berupa penundaan 
pembayaran bunga dan angsuran pokok selama 6 bulan, ketiga nasabah yang mengalami penurunan omset $50 \%$ sampai dengan $75 \%$ memperoleh kebijakan penundaan pembayaran bunga selama 6 bulan dan penundaan agsuran pokok selama hingga 12 bulan, dan keempat nasabah yang mengalami penurunan omset $75 \%$ mendapatkan kebijakan penundaan pembayaran bunga selama 12 bulan dan penundaan angsuran pokok selama 12 bulan.

Sabri (2016) melakukan penelitian mengenai analisis persepsi nasabah mengenai persepsi nasabah terhadap faktor-faktor yang mempegaruhi kredit macet pada PT Bank Perkreditan Rakyat (BPR) Padang Tarab Kecamatan Baso Kabupaten Agam. Hasilnya adalah adapun faktor-faktor yang mempengaruhi seperti tingkat suku bunga pinjaman, kolektibilitas, jangka waktu pinjaman, stabilitas penjualan nasabah dan prinsip pemberian kredit memiliki pengaruh terhadap terjadinya kredit macet. Menurut persepsi nasabah untuk meminimalisir kredit macet yang pertama yaitu dengan cara pihak Bank melakukan upaya pencegahan atau upaya yang dilakukan sebelum terjadi adanya kredit macet, dengan melakukan survei usaha nasabah dengan tepat dan akurat selain itu dengan menghitung kemampuan bayar nasabah yang hendak mengajukan pinjaman. Kemudian yang kedua yaitu dengan melakukan upaya penanganan atau upaya yang dilakukan setelah terjadi adanya kredit macet yaitu dengan cara pihak bank melakukan penagihan dan pendekatan dengan nasabah untuk mengetahui penyebab mengapa nasabah tidak dapat membayar, setelah itu pihak bank dapat memberikan solusi dengan cara memberi keringanan dalam bentuk perpanjangan kredit atau rekstrukturisasi kredit dan menyita atau menjual agunan milik nasabah.

\section{Kesimpulan, Keterbatasan, dan Implikasi Hasil Penelitian}

Dalam bagian simpulan akan menguraikan penjelasan berdasarkan dari apa yang telah diteliti oleh peneliti, adapun paparan atau deskripsi hasil pembahasan atau kesimpulan dari fokus penelitian adalah sebagai berikut:

1. Dalam prosedur pemberian kredit di Bank $\mathrm{XYZ}$ terdapat persyaratan jika nasabah yang hendak mengajukan pinjaman juga menyertakan agunan dan mutasi saldo rekening tabungan nasabah, namun adanya persyaratan tersebut tidak tercantum di website Bank XYZ.

2. Pinjaman yang diberikan Bank $X Y Z$ khususnya jenis pinjaman KUR (Kredit Usaha Rakyat) utamnya diperuntukan bagi masyarakat yang hendak mendirikan usaha atau melakukan pengembangan usaha. Namun ada sebagian dana yang digunakan untuk keperluan pribadi nasabah dan ada juga yang mendepositokan dana pinjaman di bank lain, tetapi meskpiun demikian tujuan nasabah dalam mengajukan pinjaman adalah utamanya untuk keperluan usaha dan selebihnya untuk keperluan diluar usaha.

3. Menurut persepsi nasabah yang memiliki pinjaman KUR di Bank XYZ Madiun faktor penyebab kredit macet utamanya karena kegagalan bisnis nasabah, kemudian saat ini sedang terjadi pandemi covid-19 yang menyebabkan penurunan ekonomi dan penurunan pendapatan bagi setiap pelaku usaha. Hal tersebut yang menyebabkan dana atau hasil usaha nasabah hanya cukup untuk memenuhi kebutuhan operasional usahanya saja dan tidak ada dana yang digunakan untuk membayar angsuran

4. Dalam upaya pencegahan dan penanganan kredit macet, bentuk pencegahannya yaitu dengan melakukan survei usaha nasabah dengan berfokus kepada peluang nasabah dalam memperoleh pendapatan atau memperhatikan rantai bisnis nasabah seperti mengetahui pangsa pasar usaha nasabah. Bentuk penangan yang dapat dilakukan yaitu dengan cara rekstrukturisasi kredit atau perpanjangan masa kredit yang dilakukan oleh pihak Bank XYZ, dengan adanya rekstrukturisasi akan dapat meringkan beban nasabah yang mengalami kredit macet terlebih lagi selama masih dalam masa pandemi seperti saat ini.

\section{Saran}

Setelah melakukan penelitian di lapangan dan menguraikan hasil penelitian terkait fokus masalah yaitu persepsi debitur atau nasabah yang memiliki pinjaman KUR di Bank XYZ Madiun dalam upaya pencegahan dan penanganan kredit macet dengan tujuan untuk meminimalisir adanya kredit macet. Adapun 
berikut ini adalah saran yang dapat digunakan sebagai referensi untuk perbaikan antara lain:

1. Bagi Bank

a) Dalam prosedur pemberian kredit mengenai persyaratan dan kelengkapan yang harus dipenuhi nasabah yang hendak mengajukan permohonan kredit seperti adanya agunan dan mutasi saldo rekening tabungan nasabah seharusnya juga tetera dalam website .

b) Melakukan analisis mengenai penggunaan dana pinjaman nasabah terkait dana tersebut harus direalisasikan untuk keperluan usaha.

c) Melakukan survei yang lebih berfokus kepada rantai bisnis nasabah yaitu mengetahui peluang atau sumber pendapatan nasabah atau mengetahui pangsa pasar usaha milik nasabah.

2. Bagi Peneliti Selanjutnya

a) Peneliti selanjutnya sebaiknya melakukan penelitian dengan lebih berfokus pada usaha nasabah, mengetahui secara detail mengenai tahapan awal pada saat pengajuan kredit sampai keputusan kredit diterima dan mengetahui penggunaan dana pinjaman nasabah.

b) Peneliti selanjutnya dapat melakukan penelitian terkait hambatan yang terjadi pada saat hendak mengajukan kredit yaitu mengenai penyebab proses pencairan kredit yang memerlukan waktu yang cukup lama.

c) Peneliti selanjutnya dapat melakukan penelitian mengenai analisis karakter nasabah yang juga menjadi penyebab adanya kredit macet, karena masih ditemui adanya nasabah yang melakukan pembayaran tidak tepat waktu atau tidak sesuai dengan tanggal jatuh tempo yang telah ditetapkan.

\section{Daftar Pustaka}

Afriana, A. (2017). Analisis Implementasi 6C Terhadap Kelancaran Pengembalian Kredit. In Prosiding SENMAKOMBIS (Seminar Nasional Mahasiswa Ekonomi dan Bisnis) (Vol. 1, No. 1, pp. 112-120).

Anasthasia, D. D., Darmawan, N. A. S., SE, A., Werastuti, D. N. S., \& SE, A. (2015). Analisis Sistem Pengendalian Intern dalam
Pemberian Kredit Mikro Pada PT. Bank Rakyat Indonesia (Persero), Tbk Unit Banyuasri. JIMAT (Jurnal Ilmiah Mahasiswa Akuntansi) Undiksha, 3(1).

Azisri, Y. Z. (2017). Pencegahan dan Penananganan Masalah Kredit Macet bagi Nasabah Perbankan di Kampung Sidomulyo Kabupaten Merauke. Jurnal AlQadau: Peradilan dan Hukum Keluarga Islam, 4(2), 345-356. https://doi.org/10.24252/alqadau.v4i2.5689.

Fahmi, I. (2014). Manajemen Perkreditan. Bandung: Alfabeta.

Hasibuan, M. S. (2009). Dasar-Dasar Perbankan (Jakarta: PT. Bumi Aksara).

Hohedu, T. R., \& Dewi, A. R. (2019). Penanganan Kredit Macet pada BRI Cabang X. Jurnal Ilmiah Bisnis dan Perpajakan, 1(1), 34-43.

Hutauruk, D. M. (2019). Kredit Bermasalah Perbankan Meningkat di Awal Tahun. Keuangan Kontan Online. Retrieved from https://keuangan.kontan.co.id/news/kreditbermasalah-perbankan-meningkat-di-awaltahun.

Ismail, M. B. A. (2015). Akuntansi Bank: Teori dan Aplikasi dalam Rupiah. Prenada Media.

Mahadi, T. (2019). Bank BRI Dapat Plafon KUR Rp 120,2 Triliun Pada Tahun 2020 nanti. Keuangan Kontan Online. Retrieved from

https://keuangan.kontan.co.id/news/bankbri-dapat-plafon-kur-rp-1202-triliun-padatahun-2020-nanti.

Manullang, M. (2013). Pengantar Bisnis. Jakarta: PT. Indeks.

Mulyadi. (2017). Sistem Akuntansi. Jakarta: Salemba Empat.

Nawangsari, Y., \& Putra, I. S. (2016). Analisis Sistem Pengendalian Intern Pemberian Kredit Dalam Menurunkan Tingkat Kredit Macet Pada Koperasi Simpan Pinjam "Kharisma Mitra Karya “. Jurnal Kompilasi Ilmu Ekonomi (KOMPILEK), 8(1), 67-80.

Keuangan, O. J. (2019). Laporan Publikasi Bulanan Neraca..

Pato, S. (2013). Analisis Pemberian Kredit Mikro Pada Bank Syariah Mandiri Cabang Manado. Jurnal EMBA: Jurnal Riset Ekonomi, Manajemen, Bisnis dan Akuntansi, 1(4).

Rahmawati, A. T., Saifi, M., \& Hidayat, R. R. (2016). Analisis Keputusan Pemberian 
Kredit Dalam Langkah Meminimalisir Kredit Bermasalah (Studi kasus pada Kredit Umum PT. Bank Rakyat Indonesia (persero) Tbk unit Slawi 1, Kab Tegal Jawa tengah). Jurnal Administrasi Bisnis, 35(1), 179-186.

Sabri, S. (2016). Analisis Persepsi Nasabah Terhadap Faktor-Faktor Yang Mempengaruhi Kredit Macet Pada PT. Bank Perkreditan Rakyat (BPR) Padang Tarab Kecamatan Baso Kabupaten Agam. jurnal ekonomi, 20(2), 218-230.

Papalangi, R. S. (2013). Penerapan Spi Dalam Menunjang Efektivitas Pemberian Kredit UKM Pada PT. BRI (Persero) Tbk Manado. Jurnal EMBA: Jurnal Riset Ekonomi, Manajemen, Bisnis dan Akuntansi, 1(3).

Prasadhana, D. D., Sulindawati, N. L. G. E., \& Sinarwati, N. K. (2017). Analisis Sistem Pengajuan Kredit Dan Implementasi Pengendalian Internal Dalam Pemberian Kredit Mikro Usaha Kecil Menengah Pada PT. Bank Rakyat Indonesia (PERSERO), TBK UNIT Banyuatis. JIMAT (Jurnal
Ilmiah Mahasiswa Akuntansi) Undiksha, 7(1).

Indonesia, P. R. (1998). Undang-Undang Republik Indonesia Nomor 10 Tahun 1998 Tentang Perubahan Atas Undang-Undang Nomor 7 Tahun 1992 Tentang Perbankan.

Putra, N. S., Widarsono, A., \& Nasim, A. (2013). Analisis Penerapan Sistem Pengendalian Internal Untuk Mencegah Kredit Macet Pembiayaan Musyarakah Modal Kerja Yang Diberikan Oleh Bank. Jurnal ASET (Akuntansi Riset), 5(2), $1-10$.

Wiratmini, N. P. E. (2020). Halo Nasabah, Begini Cara Minta Keringanan Kredit di Bank BRI. Finansial Bisnis Online. Retrieved from https://finansial.bisnis.com/read/20200430/ 90/1234848/halo-nasabah-begini-caraminta-keringanan-kredit-di-bank-bri .

Yuliana, E. W., \& Widianti, H. (2015). Sistem Pemberian Kredit pada Unit Simpan Pinjam KUD Karya Mina Kota Tegal. Monex: Journal Research Accounting Politeknik Tegal, 3(1). 